\title{
Estudio molecular en harinas de Oxalis tuberosa obtenidas mediante diferentes condiciones de secado
}

\author{
Molecular study in flours of Oxalis tuberosa obtained by means different drying conditions \\ González Cervantes María Eugenia ${ }^{1}$, Vargas Torres Apolonio ${ }^{1}$, Hernández Uribe Juan \\ Pablo $^{1}$, Guzmán Ortiz Fabiola Araceli ${ }^{2}$, Román Gutiérrez Alma Delia ${ }^{2}$
}

\begin{abstract}
:
The objective of this work was to know the main physicochemical changes of flour made with Oxalis tuberosa by means of two drying conditions: Freeze drying and hot air drying. The following studies were carried out: the scanning electron microscopy showed ovoid and elliptical shapes in the starch granules. With laser diffraction the particle size at 50\% (Dv50) of the flour obtained by freeze drying (HL) was: $48.5 \mu \mathrm{m}$ and for the flour obtained by hot air drying (HS) of $75.92 \mu \mathrm{m}$, presenting a bimodal distribution the flours. Studies with X-ray diffraction reported differences in the percentage of crystallinity obtaining values of 55.97\% for HL and $43.49 \%$ for HS. The brightness values (L) were 65.35 and 68.23 for HS and HL respectively. The values red / green $(\mathrm{a} *)$ and yellow / blue (b *) showed the highest redness in HL and the highest yellowness in HS. The peak viscosities were in HL of $2976 \mathrm{cP}$ and HS of 2776.25 cP.
\end{abstract}

\section{Keywords:}

Oxalis tuberosa; obtaining flour, physicochemical properties, molecular changes

\section{Resumen:}

El objetivo de este trabajo fue conocer los principales cambios fisicoquímicos de la harina elaborada con Oxalis tuberosa mediante dos condiciones de secado: liofilización y secado con calor. Se realizaron los siguientes estudios: la microscopía electrónica de barrido mostró formas ovoide y elíptica en los gránulos de almidón. Con difracción de rayos láser el tamaño de partícula al 50\% ( $\left.\mathrm{D}_{\mathrm{v}} 50\right)$ de la harina obtenida por liofilización (HL) fue: $48.5 \mu \mathrm{m}$ y para la harina obtenida por secado con calor de convección (HS) de $75.92 \mu \mathrm{m}$, presentando una distribución bimodal las harinas. Los estudios con difracción de rayos X reportaron diferencias en el porcentaje de cristalinidad obteniéndose valores de 55.97\% para HL y de $43.49 \%$ para HS. Los valores de luminosidad (L) fueron de 65.35 y 68.23 para HS y HL respectivamente. Los valores rojo/verde $\left(a^{*}\right)$ y amarillo/azul $\left(b^{*}\right)$ mostraron la mayor rojez en HL y la mayor amarillez en HS. Las viscosidades pico fueron en HL de $2976 \mathrm{cP}$ y HS de $2776.25 \mathrm{cP}$.

\section{Palabras Clave:}

Oxalis tuberosa; obtención de harinas, propiedades fisicoquímicas, cambios moleculares

\section{INTRODUCTION:}

Oxalis tuberosa is a tuber endemic from the Andes which was introduced two hundred years ago in Mexico, according to Cortella A., R., and Pochettino M., L., (1995). The obtention of flour from this tuber is one of the best ways to preserve its useful life. Choosing the drying method is a challenge. Heat drying is one of the best preservation methods that can extend the shelf life of this tuber. However, the quality of the products may change. On the other hand, frozen drying is one of the most advanced dehydration methods from which higher quality products are obtained, (Ahmed J., and Al-Attar H. (2015). Therefore, the objective of this research is to evaluate the effect of the drying method in the obtention of Oxalis tuberosa flour on its molecular, morphological, physicochemical and viscosity properties.

Autor de Correspondencia, Universidad Autónoma del Estado de Hidalgo, Instituto de Ciencias Agropecuarias, Email: apolovt@hotmail.com, maruglecer@gmail.com, heurjupa@gmail.com 


\section{MATERIALS AND METHODS:}

Oxalis tuberosa flours from potato were obtained freeze drying at $-41^{\circ} \mathrm{C}(\mathrm{HL})$ and hot air drying at $45^{\circ} \mathrm{C}(\mathrm{HS})$. The flours were characterized by techniques: scanning electron microscopy; X-ray diffraction; laser diffraction; color and the application of Rapid Viscosity Analysis (RVA).

\section{RESULTS:}

Scanning electron microscopy (SEM)

Scanning electron microscopy (SEM) showed the morphology of flours with ovoid and elliptical starch granules. Similar shapes to these were reported in a study performed on oca (Oxalis tuberosa) starch (Cruz et al., 2016). Also, more agglomerates are observed in HS (Fig. 1) probably due to the obtention process of heat-dried convection flour where the protein matrix causes the aggregation of the starch granules as reported in rice flours by Leewatchararongjaroen and Anuntagool (2016). In addition, it could be observed that the starch granules of the flours seem to be surrounded by a remarkable amount of other material like "raising powder" which is probably fibers and proteins. Similar micrographs were presented in a study conducted in yam by Chen et al, (2017).

\section{X-RAY DIFFRACTION}

According to the X-ray diffraction studies, the flours showed the B-type crystallinity pattern, characteristic of the tubers and roots that present amylopectin double helices packed in hexagonal form and with 36 water molecules (Buléon et al., 1998) starting at angle $2 \theta$ with 5 $\circ$ and presenting the maximum relative intensity at $16.9^{\circ}$ with percentages of crystallinity for $\mathrm{HL}$ of $55.97 \%$ and for $\mathrm{HS}$ of $43.49 \%$ in the same order. This is probably due to the fact that the crystalline structure of the flour starch granules made with heat-dried tuberous Oxalis tuberosa was mainly affected by the rearrangement of the intermolecular and double-helical structures during the heat-humidity treatment Hung et al., (2017).

\section{PARTICLE SIZE}

Regarding the particle size in the samples of the $\mathrm{HL}$ and HS flours, a bimodal particle size distribution was obtained (Fig. 2). The same behavior was reported in chestnut flour by similar methods of obtention Ahmed and Al-Attar (2015). The particle size at $50 \%$ (Dv50) of HL volume distribution was: $48.5 \mu \mathrm{m}$ and for HS flour of $75.92 \mu \mathrm{m}$. Possibly, smaller particles are due to the formation of more porous particles obtained by sublimation of water during freeze drying (Krokida et al., 1998). As mentioned above, the agglomeration in HS causes a greater particle size.
Viscosity studies showed a peak viscosity with significant differences between the two HL flours: $2976.00 \mathrm{cP}$ and HS: $2776.25 \mathrm{cP}$. This may be due to the different particle sizes. In general, a fine particle size has the highest swelling power and forms a rigid gel structure that results in additional strength compared to a coarse particle size (Chen et al., 2003b); Hatcher et al., (2002). Also, the highest viscosity in the $\mathrm{HL}$ sample may be due to the amount of total starches and the amylose content in the samples Ahmed and Al-Attar (2015). By observing the pasting temperatures of $\mathrm{HL}$ of $64.18^{\circ} \mathrm{C}$ and $\mathrm{HS}$ of 64.65 $\circ \mathrm{C}$ respectively.

\section{THERMAL PROPERTIES}

Through the DSC studies, similar glass transition temperatures were detected for the two flours that oscillated in $\mathrm{HL}$ of $62.91^{\circ} \mathrm{C}$ for $\mathrm{HL}$ and $62.55^{\circ} \mathrm{C}$ for $\mathrm{HS}$. The thermal properties showed that the drying processes affected neither the gelatinization temperatures of the flours dispersions nor $\Delta \mathrm{H}$. Both flours presented similar temperatures of pasting and gelatinization. By which, it is presumed that the methods of obtaining the flours were adequate. Table 1 shows the results of viscosity and differential scanning calorimetry obtained from the flours.

\section{COLOR}

Regarding the color, the $L$ value of the flour HS is 65.35 lower than the $\mathrm{HL}$ of 68.23 value which indicates that it is darker. The lowest value of $\mathrm{a}^{*} 7.68$ was found in $\mathrm{HS}$ and in $\mathrm{HL}$ to * 8.80 showing greater redness. This increase is possibly due to the anthocyanins which are responsible for giving the red color to food. The values for $b$ * show an inverse behavior of HS 7.62 and HL 5.93 which indicates that HS presents more yellowness perhaps due to the enzymatic and non-enzymatic reactions during the thermal treatment in the drying process.

\section{CONCLUSIONS:}

As it is observed in the study of the drying methods: freeze drying and hot air drying affect the morphological, structural and molecular properties of flours such as crystallinity, particle size, damage to starch, viscosity. This study may be the beginning for these flours to be incorporated into the food industry in the development of new products as components or functional food ingredients. Although there were smaller differences in other properties, this research gives us more information about the structure of Oxalis tuberosa flours obtained through two drying conditions which can help select the method of obtention and its possible application in the food industry.

\section{REFERENCES:}

\section{VISCOSITY}


Ahmed J., y Al-Attar H. (2015). Effect of drying method on rheological, thermal, and structural properties of chesnut flour doughs. Food Hydrocolloids. No. 51, pp. 76-87.

Buléon A., Colonna P, Planchot V., and Ball S. (1998). Starch granules: structure and biosynthesis. International Journal of Biological Macromolecules. No. 23, pp. 85-112

Cortella A., R., y Pochettino M., L., (1995). Comparative morphology of starch of three Andean tubers. Starch/Stärke. No. 47, pp. 455-461.

Cruz, G., Ribotta, P., Ferrero C., Iturriaga, L. (2016). Physicochemical and rheological characterization of Andean tuber starches: Potato (Solanum tuberosum ssp. Andigenum), Oca (Oxalis tuberosa Molina) and Papalisa (Ullucus tuberosus Caldas). Starch/Stärke. No. 68, pp. $1084-1094$.

Chen, Z., Schols, H.A., Voragen, A.G.J., 2003b. Starch granule size strongly determines starch noodle processing and noodle quality. Journal of Food Science: Food Chemistry and Toxicology. No. 5(68), pp. 1584-1589.

Chen, X., Li., X., Mao, X., Huang., H., Wang, T., Qu, Z., Gao, W. (2017) Effects of drying processes on starch-related physicochemical porperties, bioactive and antioxidant properties of yams fluor. Food Chemistry. No. 224, pp. 224-232.

Hatcher, D.W., Anderson, M.J., Desjardins, R.G., Edwards, N.M., Dexter, J.E. (2002). Effect of flour particle size and starch damage on processing and quality of white salted noodles. Cereal Chemistry No 79 (1), pp. 64-71.

Hung P. V., Huongb N. T. M., Phic N. T. L., Tiena N. N. T. (2017). Physicochemical characteristics and in vitro digestibility of potato and cassava starches under organic acid and heat-moisture treatments. International Journal of Biological Macromolecules. No. 95, pp. 299305 .

Krokida, M. K., Tsami, E., y Maroulis, Z. B. (1998). Kinetics on colour changes during drying of some fruits and vegetables. Drying Technology. No. 16(3-5), pp. 667-685.

Leewatchararongjaroen, J. y Anuntagool, J. (2016). Effects of Dry-Milling and Wet-Milling on Chemical, Physical and Gelatinization Properties of Rice Flour. Rice Science. No. 23(5), pp. 274-281.

\begin{tabular}{|c|c|c|c|c|c|}
\hline $\begin{array}{l}\text { Sam } \\
\text { ple }\end{array}$ & $\begin{array}{l}\text { Peack } \\
\text { viscos } \\
\text { ity } \\
\text { cP }\end{array}$ & $\begin{array}{l}\text { Final } \\
\text { viscos } \\
\text { ity } \\
\text { cP }\end{array}$ & $\begin{array}{l}\text { Pasting } \\
\text { temperat } \\
\text { ure } \\
{ }^{\circ} \mathrm{C}\end{array}$ & $\begin{array}{l}T_{p} \\
{ }^{\circ} \mathrm{C}\end{array}$ & $\begin{array}{c}\Delta H_{g} \\
J / g\end{array}$ \\
\hline HL & $\begin{array}{l}2976 \pm \\
76.66^{b}\end{array}$ & $\begin{array}{c}1920.7 \\
5 \pm \\
22.54^{\mathrm{a}}\end{array}$ & $\begin{array}{c}64.18 \pm \\
0.49^{\mathrm{a}}\end{array}$ & $\begin{array}{l}62 . \\
91\end{array}$ & $\begin{array}{l}4.1 \\
65\end{array}$ \\
\hline HS & $\begin{array}{c}2776.2 \\
5 \pm \\
27.21^{\mathrm{a}}\end{array}$ & $\begin{array}{c}1935.7 \\
5 \pm \\
59.28^{\mathrm{a}}\end{array}$ & $\begin{array}{c}64.65 \pm \\
0.40^{\mathrm{a}}\end{array}$ & $\begin{array}{l}62 . \\
55\end{array}$ & $\begin{array}{l}4.7 \\
69\end{array}$ \\
\hline \multicolumn{6}{|c|}{$\begin{array}{l}\text { Values shown are the mean } \pm \text { standard deviation; } n \\
=3 \\
\text { Means with different letter on the column different } \\
\text { significance }(P<0.05)\end{array}$} \\
\hline
\end{tabular}

